\title{
Assessment of contamination by trace metals and petroleum hydrocarbons in sediments from the tropical estuary of Todos os Santos Bay, Brazil
}

\author{
Joil José Celino ${ }^{1}$, Olívia Maria Cordeiro de Oliveira ${ }^{1}$, Gisele Mara Hadlich ${ }^{1}$, \\ Antônio Fernando de Souza Queiroz ${ }^{1}$ \& Karina Santos Garcia ${ }^{1}$
}

\begin{abstract}
As part of the environmental assessment within Todos os Santos Bay, State of Bahia - Brazil, in summer of 2005, superficial water and sediments samples of the mangrove were collected at five locations to determine the spatial distribution of anthropogenic pollutants in the Dom João estuary at the São Francisco do Conde Region. Sandy sediments with low organic matter content dominate the studied area. Trace metal levels indicated that sediments were moderately polluted with $\mathrm{Cu}$ (overall mean: $21.48+/-4.76 \mu \mathrm{g} \cdot \mathrm{g}^{-1}$ dry sediment), but not with $\mathrm{Pb}(15+/-8), \mathrm{Zn}(38+/-10), \mathrm{Cr}(15+/-7)$, Ni $(13+/-6)$ and $\mathrm{Cd}(0.4+/-0.2)$. Depending on location, total petroleum hydrocarbons ranged from 1.6 to $10.6 \mu \mathrm{g} \cdot \mathrm{g}^{-1}$. To discriminate pattern differences and similarities among samples, principal component analysis (PCA) was performed using a correlation matrix. PCA revealed the latent relationships among all the stations investigated and confirmed our analytical results. Principal components analysis confirmed two regions according to their environmental quality. The results pointed out that almost all the area presented some substances that can cause adverse biological effects, especially in the outermost region where some metals are above TEL level.
\end{abstract}

Keywords: environmental assessment, hydrocarbon, metals, sediments, mangrove, Todos os Santos Bay.

Resumo Avaliação da contaminação por metais traço e hidrocarbonetos de petróleo nos sedimentos de um estuário tropical da Baía de Todos os Santos, Brasil. Como parte da avaliação ambiental da baía de Todos os Santos, Bahia - Brasil, no verão de 2005, amostras de água superficial e sedimentos do manguezal foram coletados em cinco locais para determinar a distribuição espacial dos poluentes antropogênicos no estuário do rio Dom João na região de São Francisco do Conde. Sedimentos arenosos com baixo teor de matéria orgânica dominam a área de estudo. Níveis de metais traço indicaram que os sedimentos foram moderadamente poluídos com $\mathrm{Cu}$ (média geral: $21,48+/-4,76 \mu \mathrm{g} . \mathrm{g}^{-1}$ sedimento seco), mas não com $\mathrm{Pb}(15+/-8)$, Zn (38 +/- 10), Cr (15 +/- 7), Ni (13+/- 6) e Cd (0,4+/- 0,2). Dependendo da localização, os hidrocarbonetos totais de petróleo variaram de 1,6 para 10,6 $\mu \mathrm{g} \cdot \mathrm{g}^{-1}$. A análise da componente principal (ACP) revelou as principais relações entre as variáveis e as estações investigadas e confirmou os resultados analíticos. Análise das componentes principais confirma a distinção entre duas regiões de acordo com a sua qualidade ambiental. Os resultados apontam que quase toda a área apresentou algumas substâncias que podem causar efeitos biológicos nocivos, especialmente na região costeira, onde alguns metais estão acima do nível TEL.

Palavras-chave: avaliação ambiental, hidrocarbonetos, metais, sediments, manguezais, Baía de Todos os Santos.

INTRODUCTION Coastal wetlands are among the most biologically important and productive ecosystems on earth. Coastal wetlands also possess high socioeconomic values. They play important roles in the protection of shorelines and banks from erosion and can be used to treat domestic and industrial wastewaters.

Contamination of the aquatic environment has become a serious problem in many parts of the world, with rivers and bays often seriously affected. Almost all marine coastal ecosystems have complex structural and dynamic characteristics that can be easily modified by human influence. Estuarine and marine sediments are sinks for various metals transported from the land. Metals may be mobilized as a result of natural processes (e.g. weathering and erosion of geological formations) as well as by anthropogenic activity (e.g. Förstner and
Salomons, 1980; Fedo et al., 1996; Nesbitt et al., 1996; Nath et al., 2000; Adamo, 2005). In the mobilization process, trace elements may be adsorbed by clays, can complex with organic compounds or may co-precipitate with oxides and hydroxides. As many metals occur naturally in weathered materials and drainage systems due to their presence in local rocks, the relative influence of natural and anthropogenic sources on the geochemistry of coastal sediments is not always clear. The high total concentrations of trace metals in sediments may not necessarily indicate anthropogenic contamination, because of different background levels in parent materials and sediment properties. The natural occurrence and chemical speciation of metals can also complicate the evaluation of potentially polluted aquatic sediments (Schiff and Weisberg, 1999). Therefore, for

1 - UFBA, Universidade Federal da Bahia, Instituto de Geociências, Núcleo de Estudos Ambientais, Salvador (BA), Brasil. E-mails: joil@ufba.br; olívia@ufba.br; gisele@ufba.br; queiroz@ufba.br; karina@ufba.br 
a better assessment of metal distributions within such environment, it is important to distinguish between metallic elements released by natural processes and those introduced by human-related activities (Preda \& Cox, 2000; Liaghati et al., 2003). Numerous papers and reports have been written on diverse aspects of metals in coastal sediments; excellent general surveys have been given by Förstner and Wittmann (1981) and Förstner and Salomons (1980). Furthermore, while sediment data is useful for describing trace metal occurrence and assessing their distribution in coastal plains, in spatial or vertical trend studies, errors associated with sampling and analysis can make it difficult to detect differences between sites (e.g. Kelly et al., 1994).

Numerous efforts have been made to normalize the dilution effect invoked by coarse particles on metal contaminant concentrations in sediments, in order to understand the potential factors influencing the distribution of metals among different locations in a specific study area (Acosta et al., 2009). The corresponding methods can be classified as the physical separation of different fractions in sediments and the mathematical normalization of the chemical data by a suitable sediment property (i.e. a reference element or constituent). The latter, containing ratio calculation and regression analysis, may be preferable, due to the difficulties associated with the efficiency and feasibility of mechanical separation presented in many cases (Liu et al., 2003). The reference element, a fundamental or conservative tracer of the natural metalbound phases, is assumed to have a uniform flux from the coastal bedrock. Therefore, the anthropogenic inputs of trace metals can be identified by alterations of the relationships between trace metals and the reference element (Luoma, 1990). However, there is no uniform protocol on the appropriate sediment constituent for metal concentration normalization. The common normalizers for trace metal concentrations mainly include $\mathrm{Al}, \mathrm{Fe}$, total organic carbon (TOC) and Li. However, the accuracy or reliability of either $\mathrm{Al}$ or Fe may be not suitable if the contaminant source introduces large quantities of these two elements (Tam and Yao, 1998). TOC, without a geochemical basis, is also subject to considerable influence by human activities, and is often a pollutant by itself. Relationships between $\mathrm{Li}$ and trace metals in fine-grain sediments are usually similar to those of $\mathrm{Al}$ (Daskalakis and O'Connor, 1995, Roussiez et al., 2005).

The estuary sediments are usually derived from different mineralogical sources (e.g. of fluvial origin, marine provenance and mixtures). It is often impossible to find a single representative reference site for spatial comparison to detect and quantify anthropogenic pollution. Alternatively, the background variability of metal concentrations in sediments can be estimated or corrected by a baseline model of linear regression (Daskalakis and O'Connor, 1995; Chapman and Wang, 2001). This method fully considers the background concentrations of naturally occurring substances and provides important insight into the origins of contamination.

Oil exploration started in the early 1950s in the
State of Bahia (northeastern, Brazil), when environmental issues were not relevant for coastal planning. Todos os Santos Bay (TSB) is located in Bahia State, Brazil (Fig. 1). This bay with an area of $927 \mathrm{~km}^{2}$ is the largest on the Brazilian coast. TSB is described as a coastal body of water, strongly influenced by the masses of oceanic waters, varying in salinity from 28 to 36 . These factors contribute to the low water residence time in the bay, minimizing the effects of the industrial effluents discharged into the bay. This region is influenced by tropical climate with a well defined rainy season from April to June (Queiroz \& Celino, 2008).

The studied area, called DOM JOÃO, is located in the northeast portion of Todos os Santos Bay (Fig. 1). It is a shallow area with depths varying from 0.1 to $1.2 \mathrm{~m}$. There was an oil production field of PETROBRAS adjacent to Dom João estuary. The Dom João river flow through zones with mangrove vegetation and carry wastes from industries and urban centers. There are no previous studies concerning the accumulation of contaminants in bottom sediments of this estuary. The sediment and physic-chemical data of the benthic environment in the northeast portion of Todos os Santos Bay, should contribute to the understanding of bottom dynamics, sedimentary processes and contaminant distribution patterns, including the content and distribution of total petroleum hydrocarbons and trace metals in the sediments.

MATERIAL AND METHODS Salinity, temperature, dissolved oxygen concentration, $\mathrm{Eh}$ and $\mathrm{pH}$ data of superficial water were obtained. Sediment sampling locations are shown in figure 1. At each station, five sediment samples were collected with a manual Kajac corer $(10.0 \mathrm{~cm}$ internal diameter) for the following analyses: granulometric parameters, total organic matter (OM), total organic carbon (TOC), total nitrogen (N), chromium, zinc, copper, nickel, lead, cadmium and hydrocarbons. Sampling was conducted near the seaward edge of the estuary intertidal mud flats, to represent different sedimentary conditions within the estuarine system (Fig. 1). This study is concerned with the metal distribution in stationary sediments from the bottom of de metal-polluted surface water system of the Dom João River. The sediment for the analyses corresponded to the first $3 \mathrm{~cm}$ of the sediment column. TOC and $\mathrm{N}$ were determined using ca. $0.5 \mathrm{~g}$ of freeze dried and weighed sediment, and analysis in a LECO CNS 2000. The results are presented as percentages.

Partial wet chemical leaching with single or multiple extraction agents has been used for many years to determine the distribution of trace elements amongst the phases (Thomas et al., 1994). A great many difficulties are encountered with sample handling during the sampling procedure and with the lack of selective reagents and of discrete phases (Kheboian \& Bauer, 1987; Accomasso et al. 1993).

The trace metal results $(\mathrm{Cr}, \mathrm{Zn}, \mathrm{Cu}, \mathrm{Ni}, \mathrm{Pb}$ and $\mathrm{Cd})$ correspond to mean values of duplicate analyses and are expressed in $\mu \mathrm{g} \mathrm{g}^{-1}$ dry sediment $(<63 \mu \mathrm{m})$. The 

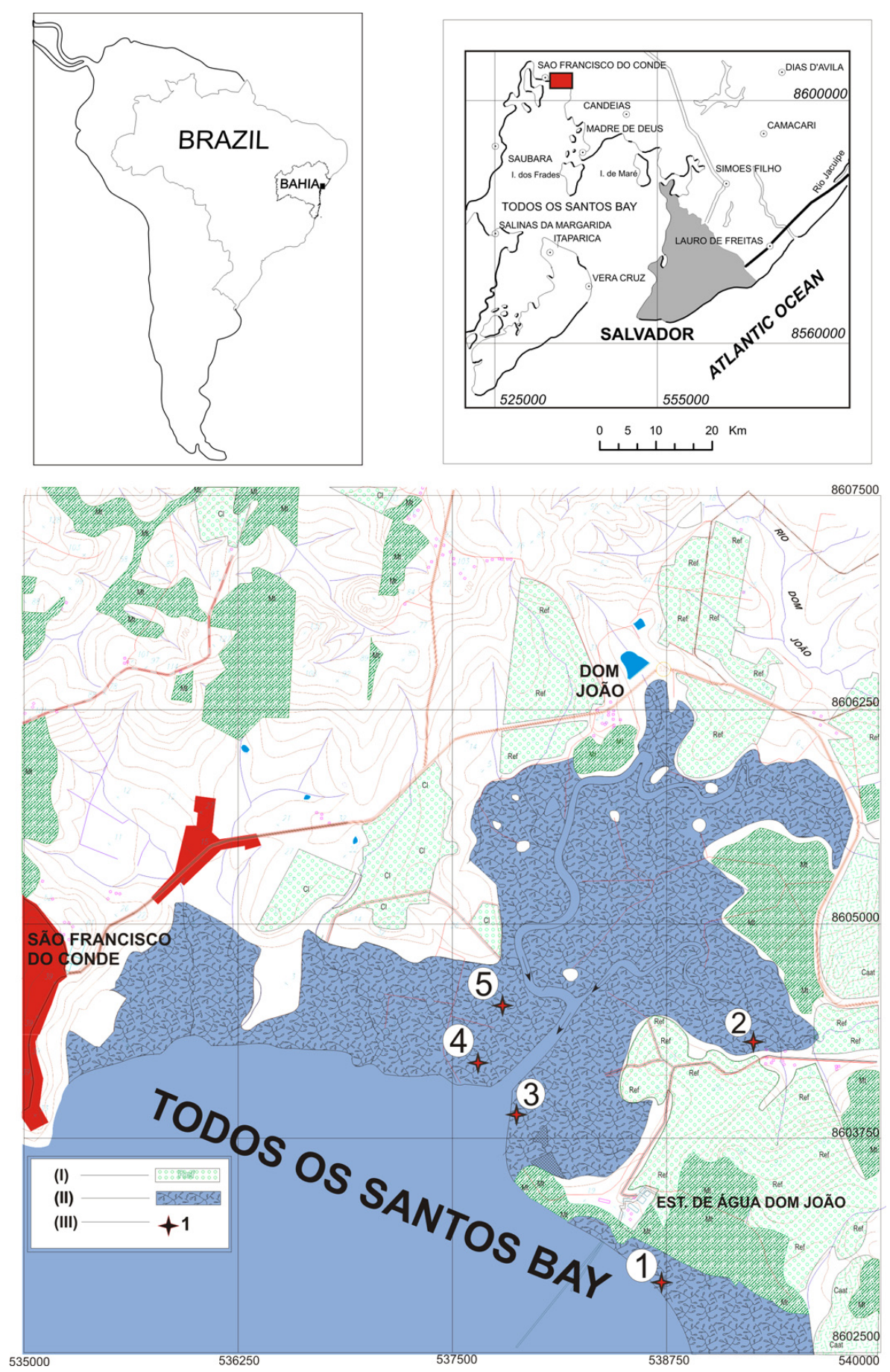

Figure 1 - Location of Todos os Santos Bay, northeastern of Bahia State Brazil - showing the sampled stations at Dom João region (Sts. 1 - 5). (I) Other vegetation; (II) mangrove and (III) stations (Sts).

variation between duplicate analyses was always less than $5 \%$. The superficial sediment of each core that passed through a PE-mesh of $63 \mu \mathrm{m}$ was dried at $85^{\circ} \mathrm{C}$ until constant weight, prior to its homogenization with an agate mortar pestle. In order to avoid interference of organic matter in the results and convert the metals to their free form, applying method No. 3051 of the EPA (Anonymous, 1990), duplicates of sub-samples (0.5$1.0 \mathrm{~g}$ ) were mixed with $10 \mathrm{~mL}$ concentrated nitric acid and digested by microwave (Provecto DGT 100 plus) in a closed fluorocarbon vessel. Quantification was performed by ASS (Varian AA-220FS) with graphite furnace atomization (Varian GFA-4B). Quality control included procedural blanks, measurement of standards obtained from the National Institute of Standards and Technology (STSD-4 Stream Sediment Samples) and spiked samples.

For trace organic contaminants, the surface sediments were placed in pre-cleaned aluminum boxes, and then stored in a freezer at $-15^{\circ} \mathrm{C}$ before laboratory analysis. The analytical procedure adopted for hydrocarbons analyses, including details of extraction, quan- 
tification and chromatography equipment, was that detailed by Celino \& Queiroz (2006).

Procedural blanks contained a few minor contaminant peaks that did not interfere with the analyses of target compounds. A spiked-recovery experiment was conducted simultaneously with sample extraction, and the recoveries ranged $70-120 \%$ for hydrocarbons.

Commonly used mean calculation methods of median, geometrical mean and arithmetical mean were involved for comparison. Pearson's Product-Moment correlations between all the sediment variables studied, were performed in order to determine the degree of relationship (Jaffé et al. 2003; Muniz et al. 2004). A significance level of $p=0.05$ was accepted. The variables were analysed for normality using KolmogorovSmirnov test and when this analysis failed to meet assumptions for parametric statistics, transformations were applied to give the best approximation to normality (Muniz et al. 2006). Correlations analysis and PCA were applied to reveal the relationships among the elements (Zhang et al. 1998).

RESULTS AND DISCUSSION In the inner region of Todos os Santos Bay, sediment grain size distribution, organic carbon and nitrogen contents (Tab. 1) were consistent with those previously reported by other authors (Lessa et al., 2001; Celino et al. 2005; Hadlich et al., 2007). It would appear that, at least potentially, the supply of particulate matter has been derived from riverine inputs. The dominance of fine sand with an important contribution of mud (Tab. 1) shows that the area can be characterized as a low energy environment.

Total organic matter (TOM) showed lowest values at those stations located in front of river mouths (Tab. 1). Total organic carbon (TOC) and TOM showed the same distribution pattern and were highly correlated (Tab. 2). Total nitrogen showed the same distribution pattern as TOC, and presented the highest correlation between the variables analyzed $(\mathrm{r}=0.659, \mathrm{p}<0.0005)$. Concerning the source of sedimentary organic matter, $\mathrm{C} / \mathrm{N}$ ratios suggested a mixed origin of the sedimentary organic matter (Jaffé et al., 2001).

In general, metal contents were low (Tab. 1, Fig. 2, 3 e 4), but some stations were highlighted for their $\mathrm{Cu}$ and $\mathrm{Cr}$ values (Fig. 2 and 3), such St. 1 and 3 for $\mathrm{Cr}$ and St. 1 for $\mathrm{Zn}$. In all cases $\mathrm{Zn}, \mathrm{Cr}$ and $\mathrm{Cu}$ were low at $\mathrm{St}$. 5 and $\mathrm{Cr}$ was low only at St. 2. These late sites are the most remote from contaminant sources and are more influenced by incoming shelf-waters. Conversely, the most outermost stations, located in the mouth of the Dom João river (Fig. 1), presented the highest concentrations of the studied trace metals, particularly St. 1 (for $\mathrm{Cu}$ and $\mathrm{Cr}$ ) and St. 3 (for $\mathrm{Cr}$ ). The three metals $(\mathrm{Cu}, \mathrm{Ni}$ and $\mathrm{Cr}$ ) analyzed showed strong positive correlations with each other, and with TOM and TOC content (Tab. 2). The lack of correlation between the metal contents and the sediment fractions suggests that their distribution is not dependent on granulometry, exception to Zn (Fig. 5). Furthermore, a high degree of association among the metals was observed, as previously reported for different urbanised and developing urban areas (Ruiz, 2001; Muniz et al., 2004). The similarity of $\mathrm{Cu}$ and $\mathrm{Zn}$ values at St. 1 and 3 could be related to the incipient tourism development of the region during the last decade. According to the EPA criteria (Anonymous, 1977), only Sts. 1 and 3 were classified as moderately polluted (MP) by $\mathrm{Cu}$ (Fig. 2, Tab. 3).

Table 1 - Physico-chemical and sedimentological variables, percentages of organic matter constituents, total petroleum hydrocarbons and metal concentration in surface sediments at five sampling stations from Dom João estuary.

\begin{tabular}{l|c|c|c|c|c}
\hline Station & 1 & 2 & \multicolumn{2}{c}{3} & \multicolumn{2}{c}{4} \\
\hline $\mathrm{pH}$ & 7.3 & 6.8 & 8.0 & 6.9 & 7.7 \\
$\mathrm{Eh}(\mathrm{mV})$ & -20 & 29 & -34 & 27 & -18 \\
$\mathrm{~T}\left({ }^{\circ} \mathrm{C}\right)$ & 28.7 & 28.6 & 35.7 & 34.6 & 31 \\
$\mathrm{Sal}(\% \mathrm{o})$ & 39 & 37 & 30 & 40 & 41 \\
$\mathrm{DO}\left(\mathrm{mg} \mathrm{L}^{-1}\right)$ & 14.7 & 6.1 & 7 & 5.8 & 7.3 \\
\hline Sand $(\%)$ & 77 & 78 & 79 & 69 & 78 \\
$\mathrm{Silt}(\%)$ & 5 & 9 & 6 & 8 & 11 \\
$\mathrm{Clay}(\%)$ & 18 & 13 & 15 & 23 & 11 \\
\hline $\mathrm{Cu}\left(\mu \mathrm{g} \mathrm{g}^{-1}\right)$ & 25.47 & 18.42 & 27.33 & 20.08 & 16.09 \\
$\mathrm{Ni}\left(\mu \mathrm{g} \mathrm{g}^{-1}\right)$ & 12.86 & 5.65 & 19.66 & 16.70 & 8.00 \\
$\mathrm{~Pb}\left(\mu \mathrm{g} \mathrm{g}^{-1}\right)$ & $<1.0$ & $<1.0$ & $<1.0$ & 20.03 & 9.27 \\
$\mathrm{Cr}\left(\mu \mathrm{g} \mathrm{g}^{-1}\right)$ & 15.59 & 5.60 & 24.60 & 20.03 & 11.60 \\
$\mathrm{Cd}\left(\mu \mathrm{g} \mathrm{g}^{-1}\right)$ & 0.30 & 0.56 & $<0.1$ & $<0.1$ & $<0.1$ \\
$\mathrm{Zn}\left(\mu \mathrm{g} \mathrm{g}^{-1}\right)$ & 40.47 & 29.46 & 39.92 & 52.22 & 27.99 \\
\hline $\mathrm{TPH}\left(\mu \mathrm{g} \mathrm{g}^{-1}\right)$ & 9.00 & 10.60 & 1.60 & 5.10 & 4.70 \\
\hline $\mathrm{TOM}(\%)$ & 5.17 & 4.13 & 4.46 & 2.99 & 1.80 \\
$\mathrm{TOC}(\%)$ & 3.00 & 2.39 & 2.59 & 1.73 & 1.04 \\
$\mathrm{~N}(\%)$ & 0.27 & 0.19 & 0.18 & 0.23 & 0.14 \\
$\mathrm{C} / \mathrm{N}$ & 11.2 & 12.6 & 14.7 & 7.7 & 7.3 \\
\hline
\end{tabular}

$\mathrm{Eh}=$ redox potential, $\mathrm{T}=$ Temperature, $\mathrm{Sal}=$ salinity, $\mathrm{DO}=$ dissolved oxygen in bottom water, $\mathrm{TPH}=$ Total petroleum hydrocarbons, $\mathrm{TOM}=$ total organic matter, $\mathrm{TOC}=$ total organic carbon, $\mathrm{N}=$ total nitrogen. 
Table 2 - Pearson correlation matrix for the variable analyzed.

\begin{tabular}{|c|c|c|c|c|c|c|c|c|c|c|c|c|c|c|c|c|}
\hline & $\mathrm{pH}$ & Eh & $\mathrm{T}$ & Sal & DO & Sand & Silt & Clay & $\mathrm{Cu}$ & $\mathrm{Ni}$ & $\mathrm{Cr}$ & $\mathrm{Zn}$ & TPH & TOM & TOC & ON \\
\hline $\mathrm{pH}$ & 1.0 & & & & & & & & & & & & & & & \\
\hline Eh & -0.9 & 1.0 & & & & & & & & & & & & & & \\
\hline $\mathrm{T}$ & 0.4 & -0.2 & 1.0 & & & & & & & & & & & & & \\
\hline Sal & -0.5 & 0.4 & -0.5 & 1.0 & & & & & & & & & & & & \\
\hline DO & 0.1 & -0.5 & -0.5 & 0.2 & 1.0 & & & & & & & & & & & \\
\hline Sand & 0.6 & -0.6 & -0.4 & -0.5 & 0.2 & 1.0 & & & & & & & & & & \\
\hline Silt & -0.1 & 0.4 & -0.1 & 0.5 & -0.6 & 0.0 & 1.0 & & & & & & & & & \\
\hline Clay & -0.4 & 0.3 & 0.4 & 0.1 & 0.1 & -0.9 & -0.5 & 1.0 & & & & & & & & \\
\hline $\mathrm{Cu}$ & 0.4 & -0.6 & 0.3 & -0.7 & 0.5 & 0.2 & -0.9 & 0.3 & 1.0 & & & & & & & \\
\hline $\mathrm{Ni}$ & 0.4 & -0.4 & 0.8 & -0.5 & 0.0 & -0.3 & -0.6 & 0.6 & 0.7 & 1.0 & & & & & & \\
\hline $\mathrm{Cr}$ & 0.5 & -0.5 & 0.9 & -0.5 & 0.0 & -0.3 & -0.6 & 0.5 & 0.7 & 1.0 & 1.0 & & & & & \\
\hline $\mathrm{Zn}$ & -0.2 & 0.2 & 0.6 & 0.0 & 0.0 & -0.8 & -0.5 & 1.0 & 0.4 & 0.8 & 0.7 & 1.0 & & & & \\
\hline ТPH & -0.8 & 0.5 & -0.9 & 0.5 & 0.3 & 0.0 & 0.0 & 0.0 & -0.3 & -0.7 & -0.8 & -0.3 & 1.0 & & & \\
\hline TOM & -0.1 & -0.2 & -0.2 & -0.5 & 0.6 & 0.3 & -0.9 & 0.2 & 0.8 & 0.3 & 0.2 & 0.2 & 0.3 & 1.0 & & \\
\hline TOC & -0.1 & -0.2 & -0.2 & -0.5 & 0.6 & 0.3 & -0.9 & 0.2 & 0.8 & 0.3 & 0.2 & 0.2 & 0.3 & 1.0 & 1.0 & \\
\hline ON & -0.5 & 0.2 & -0.2 & 0.2 & 0.7 & -0.4 & -0.7 & 0.7 & 0.5 & 0.3 & 0.2 & 0.6 & 0.5 & 0.7 & 0.7 & 1.0 \\
\hline
\end{tabular}

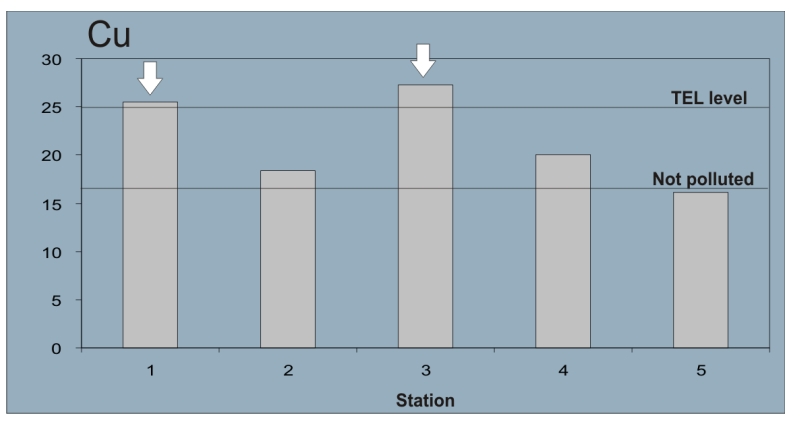

Figure 2 - Concentration ( $\mu g \mathrm{~g}^{-1}$ dry weight in

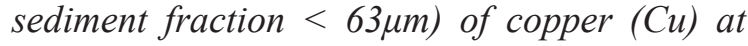
the five stations of the Dom João Estuary, Bahia-Brazil. TEL level and not-polluted level, as considered in the Environmental Protection Agency (EPA) (Anonymous, 1977, 2000), are also shown.

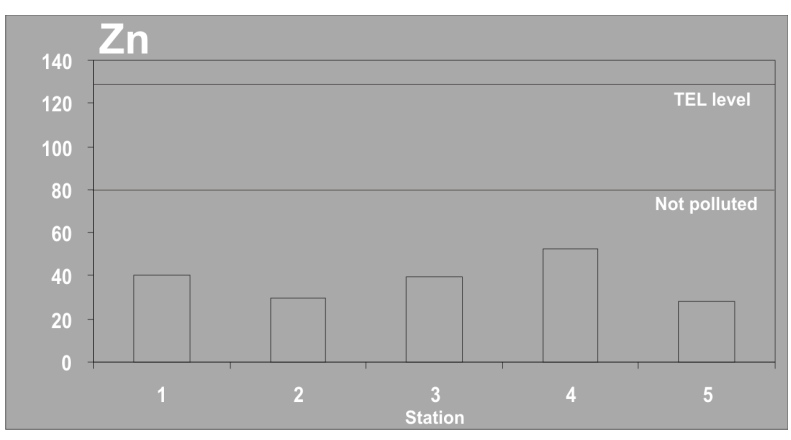

Figure 3 - Concentration ( $\mu g g^{-1}$ dry weight in

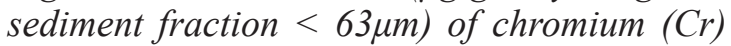
at the five stations of the Dom Joano Estuary, Bahia - Brazil. TEL level and not-polluted level, as considered in the Environmental Protection Agency (EPA) (Anonymous, 1977, 2000), are also shown.

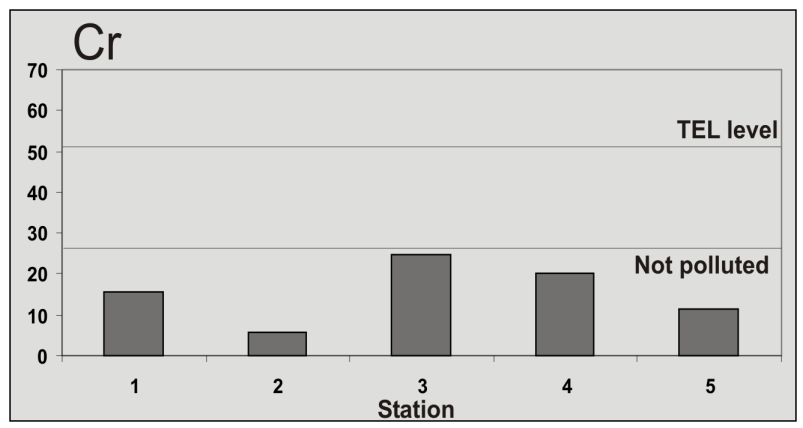

Figure 4 - Concentration ( $\mu g g^{-1}$ dry weight in sediment fraction $<63 \mu \mathrm{m})$ of zinc ( $\mathrm{Zn}$ ) at the five stations of the Dom João Estuary, Bahia - Brazil. TEL level and notpolluted level, as considered in the Environmental Protection Agency (EPA) (Anonymous, 1977, 2000), are also shown.

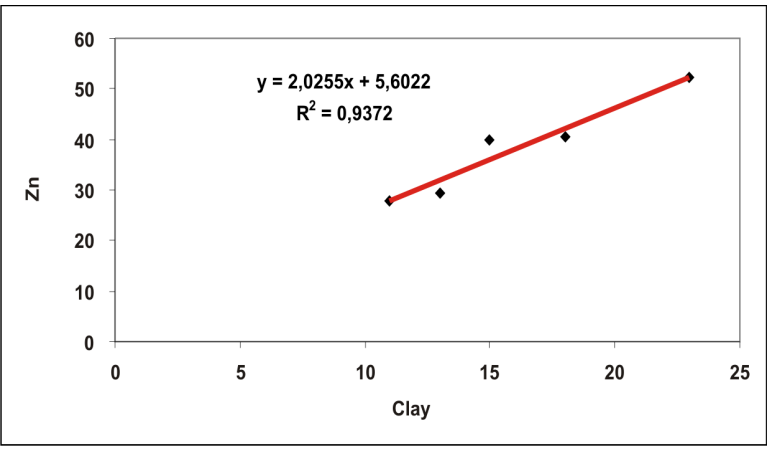

Figure 5 - The correlation between the Zn metal content and the clay sediment fraction at the five stations of the Dom João Estuary, Bahia - Brazil.

There are no apparent adverse biological effects caused by $\mathrm{Zn}$ (Tab. 3), and toxicity is rarely threatened by $\mathrm{Cr}$, only at St. 3 (Anonymous 2000).

Total petroleum hydrocarbons levels ranged be- 
tween 1.60 and $10.60 \mu \mathrm{g} \mathrm{g}^{-1}$ dry weight (Tab. 2). The highest positive correlation with TOM, TOC and total nitrogen content of the sediments could be explained by the input of by human activities. Concerning the source of sedimentary organic matter, $\mathrm{C} / \mathrm{N}$ ratios suggested a mixed origin of the sedimentary organic matter.

An "environmental variable $\mathrm{x}$ sampling sites" (variables previously standardized) matrix constructed to perform a principal component analysis (PCA) were consistent with reported by other authors (Jaffé et al. 2003; Muniz et al. 2004; Muniz et al. 2006). The PCA results showed the formation of four groups of stations (Fig. 6). The first and second components together explained $68 \%$ of the total variance; the first component alone explained $40 \%$. Granulometric influence appeared as an important primary discriminative variable. $\mathrm{PH}$ in- fluence appeared as an important secundary discriminative variable since its contribution to the explained variance was only important in axis II. The first group, formed by St. 2, was characterized by high content of TPH. Conversely, groups II (St. 5), III (St. 3) and IV (Sts. 1 and 4) showed the opposite characteristic. Discrimination between these three groups is reinforced by group III which is characterized by high $\mathrm{Cr}$ content and low TPH values (Fig. 6). Groups I and II are under the direct influence of riverine inputs that introduce to the bay domestic sewage and terrestrial material.

CONCLUSIONS Findings obtained in this investigation showed that the spatial distribution of sedimentary trace metals and organic compounds in the Dom João region were clearly affected by riverine input. The

Table 3 - Comparison of mean metal $\left(\mu \mathrm{g} g^{-1}\right)$ in the Dom João Estuary with bedrocks types, contamination standards and other systems where spatial distributions of metals in sediments have been studied.

\begin{tabular}{|c|c|c|c|c|c|c|c|}
\hline & & $\mathrm{Cu}$ & $\mathrm{Ni}$ & $\mathrm{Pb}$ & $\mathrm{Cr}$ & $\mathrm{Cd}$ & $\mathrm{Zn}$ \\
\hline \multicolumn{2}{|l|}{ Bedrock $^{1}$} & 33 & 56 & 34 & 173 & nd & 173 \\
\hline \multicolumn{2}{|c|}{ Average Shale ${ }^{2}$} & 45 & 68 & 20 & 90 & 0.3 & 95 \\
\hline \multicolumn{2}{|c|}{ Target Value ${ }^{3}$} & 36 & 35 & 85 & 100 & 0.8 & 140 \\
\hline \multicolumn{2}{|c|}{ Target Value 4} & 60 & 30 & 72 & 75 & 1.3 & 300 \\
\hline \multicolumn{2}{|c|}{ Background $^{5}$} & 17 & 9.9 & 10 & 10 & 0.2 & 23 \\
\hline \multicolumn{2}{|l|}{$\mathrm{TEL}^{5,6}$} & 25 & 18 & 35 & 52.3 & 0.6 & 123.1 \\
\hline \multicolumn{2}{|l|}{$\mathrm{PEL}^{5,6}$} & 197 & 35.9 & 91.3 & 90 & 3.53 & 315 \\
\hline \multicolumn{2}{|c|}{ Todo os Santos Bay ${ }^{7}$} & 30.91 & nd & 75.31 & 19.2 & 0.189 & nd \\
\hline \multicolumn{2}{|c|}{ Todos os Santos Bay ${ }^{8}$} & 48.67 & 29.07 & 22.86 & 60.53 & 0.49 & 94.2 \\
\hline \multicolumn{2}{|c|}{ Guanabara Bay $^{9}$} & nd & 9.3 & 59.2 & 43.3 & nd & 238.4 \\
\hline Dom João & mean & 21.48 & 12.57 & 14.65 & 15.48 & 0.43 & 38.01 \\
\hline Estuary & maxim & 27.33 & 19.66 & 20.03 & 24.60 & 0.56 & 52.22 \\
\hline
\end{tabular}

1 = Conceição (1977); 2 = Turekian and Wedepohl, 1961; 3 = Netherlands Department of Soil Protection (1994); 4 = CETESB (2005); 5 = NOAA (1999); 6 = ENVIRONMENT CANADÁ (1999), 7 = UFBA (1996); $8=$ Santos (2002); $9=$ Machado et al. (2002). nd = not determined.

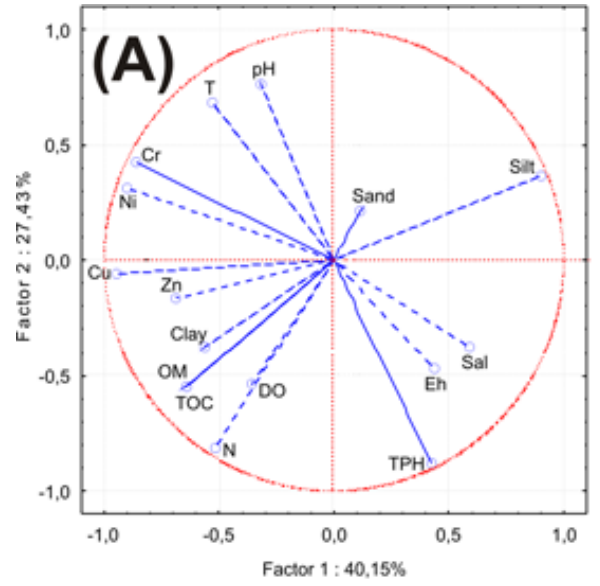

\begin{tabular}{|c|ccccc|}
\cline { 2 - 5 } \multicolumn{1}{c|}{} & Factor 1 & Factor 2 & Factor 3 & Factor 4 \\
\hline pH & $-0,3174$ & 0,7639 & 0,4742 & 0,3014 \\
Eh & 0,4427 & $-0,4699$ & $-0,6151$ & $-0,4525$ \\
T & $-0,5345$ & 0,6834 & $-0,4687$ & $-0,1663$ \\
Sal & 0,5946 & $-0,3745$ & $-0,3974$ & 0,5902 \\
DO & $-0,3586$ & $-0,5411$ & 0,4603 & 0,6055 \\
Sand & 0,1171 & 0,2163 & 0,9645 & $-0,0957$ \\
Silt & 0,9051 & 0,3677 & $-0,2134$ & 0,0016 \\
Clay & $-0,5628$ & $-0,3756$ & $-0,7317$ & 0,0826 \\
Cu & $-0,9454$ & $-0,0586$ & 0,3144 & $-0,0627$ \\
Ni & $-0,9038$ & 0,3149 & $-0,2897$ & 0,0070 \\
Cr & $-0,8625$ & 0,4239 & $-0,2545$ & 0,1080 \\
Zn & $-0,6887$ & $-0,1595$ & $-0,7047$ & 0,0598 \\
TPH & 0,4235 & $-0,8820$ & 0,1803 & $-0,1013$ \\
OM & $-0,6462$ & $-0,5502$ & 0,4500 & $-0,2777$ \\
TOC & $-0,6462$ & $-0,5502$ & 0,4500 & $-0,2777$ \\
ON & $-0,5159$ & $-0,8183$ & $-0,1511$ & 0,2036 \\
\cline { 2 - 5 } & & & & \\
\cline { 3 - 5 } & &
\end{tabular}

Figure 6 - (A) Principal component analysis (PCA) diagrams for environmental and contamination variables and eigenvalues for the factors and cumulative proportion of variance, showing their contribution for the first two axes. Axis 1 (40,15\%) correlated positively with silt, salinity (sal), Eh and total petroleum hydrocarbon (TPH). Axis 2 $(27,43 \%)$ correlated positively with $\mathrm{pH}$, T, chromium (Cr), nickel (Ni) and sand. (B) Sampling stations are represented by numbers 1-5 and eigenvalues for the factors and cumulative proportion of variance, showing their contribution for the first two axes. 


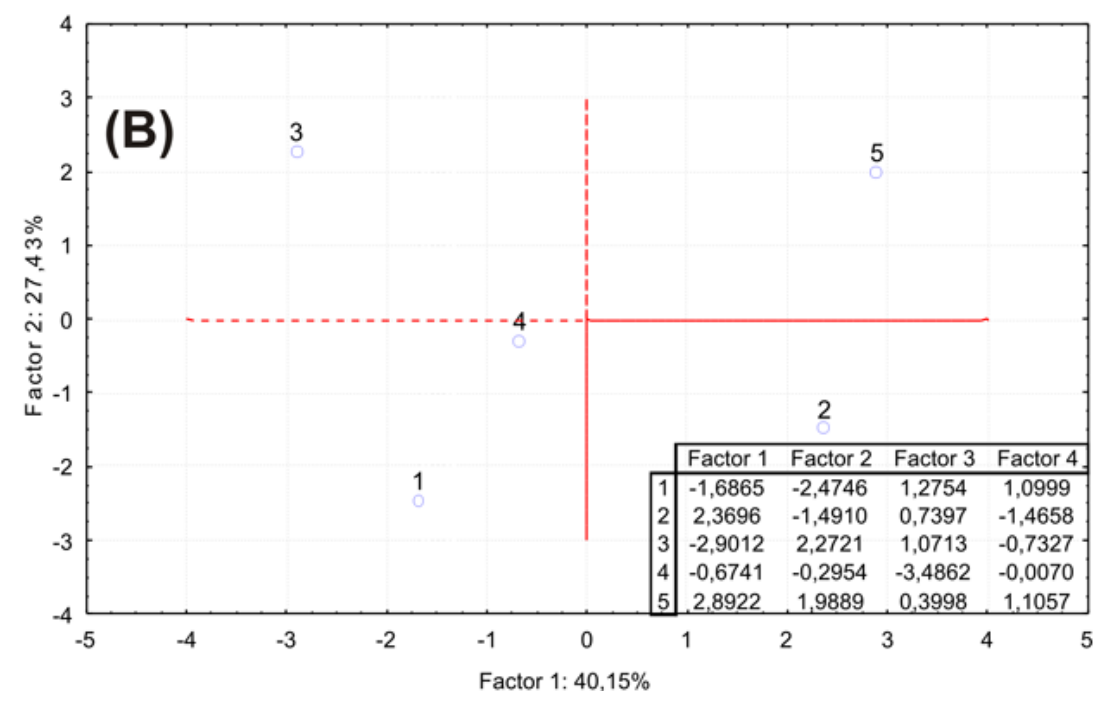

Figure 6- (B) Sampling stations are represented by numbers 1-5 and eigenvalues for the factors and cumulative proportion of variance, showing their contribution for the first two axes.

Dom João river is mainly responsible for the quality of bottom sediments, which are affected by domestic sewage, city runoff and urban activities in São Francisco do Conde city. Increasing tourism and the lack of sewage treatment systems may be responsible for the entrance of metals and TPH into the bay's water and their subsequent deposition in bottom sediments. Sts. 1 and 3, located near the mouths of the river, are the most affected locations. The clockwise water circulation pattern in the bay may contribute to the observed distribution of sediments and associated particles.

Acknowledgements This research project was supported by the financial help of the Brazilian Science and Technology Ministry Project FINEP - CT-PETRO no. 640002700 .

\section{References}

Accomasso G.M., Zelano V., Daniele P.G., Gastaldi D., Ginepro M., Ostacoli G.A. 1993. Study on the reproducibility of Tessier's extractions in a fluvial sediment and comparison between different dissolution procedures in a reference material. Spectrochim. Acta, 49A:1205-1212.

Acosta J.A., Faz Cano A., Arocena J.M., Debela F., MartínezMartínez S. 2009. Distribution of metals in soil particle size fractions and its implication to risk assessment of playgrounds in Murcia City (Spain) Geoderma, 149(12):101-109.

Adamo P., Arienzo M., Imperato M., Naimo D., Nardi G., Stanzione D. 2005. Distribution and partition of heavy metals in surface and sub-surface sediments of Naples city port Chemosphere, 61(6):800-809.

Anonymous. 1977. Implementation Manual for Section 103 of Public Law 92- 532: Marine Protection, Research and Sanctuaries Act of 1972. July 1977. U.S. Army Corps of Engineers, Environmental Effects Laboratory, Waterways Experiment Section, Vicksburg, MS.

Anonymous. 1990. Microwave assisted acid digestion of aqueous samples and extracts. SW-846. Method 3015 and 3051. Test methods for evaluating solid waste. Washington, DC: U.S. Environment Protection Agency (EPA).

Celino J.J. \& Queiroz A.F. de S. 2006. Fonte e grau da contaminação por hidrocarbonetos policíclicos aromáticos (HPAs) de baixa massa molecular em sedimentos da baía de Todos os Santos, Bahia. R. Esc. Minas, 59(3):265270.

Celino J.J., Queiroz A.F.S., Santos J.B. 2005. Heavy Metals and Petroleum Hydrocarbons in Sediments of the Mangrove from São Francisco do Conde Region, Todos os Santos Bay, Bahia.. In: Mundo Virtual, Congresso Brasileiro de P \& D em Petróleo e Gás, 3, Salvador, Boletim de Resumos, v.1. CD-Rom.

CETESB. 2005. Relatório de estabelecimento de valores orientadores para solos e águas subterrâneas no Estado de São Paulo. São Paulo: CETESB, 247p.

Chapman P.M., Wang F.Y. 2001. Assessing sediment contamination in estuaries. Environmental Toxicology and Chemistry, 20:3-22.

Conceição T.M.L. 1977. Alteração de Rochas e Sedimentos da Parte Ocidental do Recôncavo Baiano. Dissertação de Mestrado. IG, Universidade Federal da Bahia, 102p.

Daskalakis K.D., O'connor T.P. 1995. Normalization and elemental sediment contamination in the coastal states. Environmental Science and Technology, 29:470-477.

ENVIROMENT CANADA. 1999. Canadian Sediment Quality Guidelines for the Protection of Aquatic Life Summary Tables. Available: http://www.ec.gc.ca. In: 20/11/1999.

Fedo C.M., Eriksson K., Krogstad E.J. 1996. Geochemistry of shales from the Archean Abitibi greenstone belt, Canada: Implications for provenance and source-area weathering. 
Geochimica et Cosmochimica Acta, 60:1751-1763.

Förstner U. \& Salomons W. 1980. Trace metal analysis in polluted sediments. Part I: Assessment of sources and intensities. Environ. Sci. Technol., 1:494-505.

Förstner V. \& Wittmann G.T.W. 1981. Metal Pollution in the Aquatic Environment. N. York, Springer Verlag, 486p.

Hadlich G.M., Celino J.J., Ucha J.M., Santiago J.S. 2007. Geoquímica de Metais Traços em Apicuns (Planícies Hipersalinas) do Campo de Produção de Petróleo Dom João, São Francisco do Conde, Bahia.. In: Sociedade Brasileira de Geoquímica, Congresso Brasileiro de Geoquímica, 11, Atibaia, Anais, 1:1-3. CD-Rom.

Jaffé R., Mead R., Hernández M.E., Peralba M.C., Diguida O.A. 2001. Origin and transport of sedimentary organic matter in two subtropical estuaries: a comparative biomarker-based study. Organic Geochemistry,32:507-526.

Jaffé R., Gardinali P.R., Cai Y., Sudburry A., Fernandez A., Hay B.J. 2003. Organic compounds and trace metals of anthropogenic origin in sediments from Montego Bay, Jamaica: assessment of sources and distribution pathways. Environment Pollution, 123:291-299.

Kelly A.G., Wells D.E., Fryer R.J. 1994. Sampling strategy to detect a change in concentration of trace organic contaminants in marine sediment. Sci Total Environ, 144:217-230

Kheboian C. \& Bauer F. Ch. 1987. Accuracy of selective extraction procedures for metal speciation in model aquatic sediments. Anal. Chem., 59:1417-1423.

Lessa G.C., Dominguez J.M., Bittencourt A.C.S.P., Brichta A. 2001. The tides and tidal circulation of Todos os Santos Bay, Northeast Brazil: a general characterization. An. Acad. Bras. Cienc., 73(2):245-261.

Liaghati T., Preda M., Cox M. 2003. Heavy metal distribution and controlling factors within coastal plain sediments, Bells Creek catchment, southeast Queensland, Australia. Environment International., 29:935-948.

Liu W.X., Li X.D., Shen Z.G., Wang D.C., Wai O.W.H., Li Y.S. 2003. Multivariate statistical study of heavy metal enrichment in sediments of the Pearl River Estuary. Environment Pollution., 121:377-388.

Luoma S.N. 1990. Processes affecting metal concentrations in estuarine and coastal marine sediments. In: Furness R. \& Rainbow P. (eds.) Heavy Metals in the Marine Environment. CRC Press, Boca Raton, USA, p. 51-66.

Machado W., Silva-Filho E.V., Oliveira R.R. 2002. Trace metal retention in mangrove ecosystem in Guanabara Bay,SE Brazil.Marine Pollution Bulletin,44:1277-1280.

Muniz P., Danulat E., Yannicelli B., García-Alonso J., Medina G., Bícego M.C. 2004. Assessment of contamination by heavy metals and petroleum hydrocarbons in sediments of Montevideo Harbour (Uruguay). Environment International., 29:1019-1028.

Muniz P., Pires-Vanin A.M.S., Martins C.C., Montone R.C., Bícego M.C. 2006. Trace metals and organic compounds in the benthic environment of a subtropical embayment (Ubatuba Bay, Brazil). Mar. Pol. Bull., 52:1090-1117.

Nath B.N., Kunzendorf H., Pluger W.L. 2000. Influence of provenancer weathering, and sedimentary processes on the elemental ratios of the fine-grained fraction of the bedload sediments from the Vembanad Lake and the adjoining continental shelf, southwest coast of India. Journal of Sedimentary Petrology, 70:1081-1094.

NETHERLANDS DEPARTMENT OF SOILPROTECTION. 1994. Soil Protection Act. Ministry of Housing, Spatial Planning and the Environment. The Hague, The Netherlands.

Nesbitt H.W., Young G.M., Mclennan S.M., Keays R.R. 1996. Effects of chemical weathering and sorting on the petrogenesis of siliclastic sediments, with implications for provenance studies. Jl. of Geology, 104:525-542.

NATIONAL OCEANIC AND ATMOSPHERIC ADMINISTRATION (NOAA). 1999. Screening Quick Reference Tables, National Oceanic and Atmospheric Administration. Seattle, USA, 12p.

Preda M. \& Cox M.E. 2000. Sediment-water interaction, acidity and other water quality parameters in a subtropical setting, Pimpama River, Southeast Queensland. Environ Geol., 39(3-4):319-329.

Queiroz A.F.S. \& Celino J.J. (orgs.) 2008. Avaliação de Ambientes na Baía de Todos os Santos: Aspectos geoquímicos, geofísicos e biológicos. 1. ed. Salvador: UFBA, v. $1 ., 300 \mathrm{p}$.

Roussiez V., Ludwig W., Probst J-L., Monaco A. 2005. Background levels of heavy metals in surficial sediments of the Gulf of Lions (NW Mediterranean): An approach based on ${ }^{133} \mathrm{Cs}$ normalization and lead isotope measurements. Environmental Pollution, 138(1):167-177.

Ruiz F. 2001. Trace metals in estuarine sediments from the Southwestern Spanish coast. Marine Pollution Bulletin, 42:482-490.

Santos J.B. 2002. Estudos Geoquímicos em Substrato Lamoso em Zonas de Manguezal da Região de São Francisco do Conde-Recôncavo Baiano: Subsídios a um Programa de Diagnóstico e Monitoramento Ambiental Para Regiões de Manguezal influenciadas por Atividades Petroliferas. Dissertação de Mestrado, IG, UFBA, 142p.

Schiff K.C. \& Weisberg S.B. 1999. Iron as a reference element for determining trace metal enrichment in Southern California coastal shelf sediments. Marine Environment Research, 48:161-176.

Tam N.F.Y. \& Yao M.W.Y. 1998. Normalization and heavy metal contamination in mangrove sediments. The Science of the Total Environment, 216:33-39.

Thomas R.P., Ure A.M., Davidson C.M., Littlejohn D., Rauret G., Rubio R. Lopez-Sanchez J.F. 1994. Threestage sequential extraction procedure for the determination of metals in river sediments. Anal. Chim. Acta, 286:423-429.

Turekian K.K. \& Wedepohl K.H. 1961. Distribuiton of the elements in some major units of the earth's crust. Geol. Soc. of Am. Bull., 72:175-192.

Zhang C., Selinus O., Schedin J. 1998. Statistical analyses for heavy metal contents in still and root samples in an area of southeastern Sweden. The Science of the Total Environment, 212:217-232.

Manuscrito ID 11583 Submetido em 25 de junho de 2008 Aceito em 20 de dezembro de 2008 Sistema eletrônico de submissão 